\begin{tabular}{|l|l|l|l|l|}
\hline ACTA CARSOLOGICA & $32 / 1$ & 2 & $19-28$ & LJUBLJANA 2003 \\
\hline
\end{tabular}

COBISS: 1.08

\title{
THE KARST OF SALENTO REGION (APULIA, SOUTHERN ITALY): CONSTRAINTS FOR MANAGEMENT
}

\author{
KRAS V REGIJI SALENTO (APULIA, JUŽNA ITALIJA): \\ OMEJITVE PRI UPRAVLJANJU
}

GIANLUCA SELLERI ${ }^{1} \&$ PAOLO SANSÒ $^{2} \&$ NICOLA WALSH $^{1}$

\footnotetext{
${ }^{1}$ Dipartimento di Geologia e Geofisica, Università di Bari; BARI, ITALIA, e-mail: gselleri@geo.uniba.it; n.walsh@geo.uniba.it

${ }^{2}$ Osservatorio di Chimica, Fisica e Geologia Ambientali, Dipartimento di Scienza dei Materiali, Università di Lecce; LECCE, ITALIA, e-mail: paolo.sanso@unile.it
} 


\section{Abstract \\ UDC: 551.44(450.75) \\ Gianluca Selleri \& Paolo Sansò \& Nicola Walsh: The karst of Salento region (Apulia, Southern Italy): constraints for management}

The Salento peninsula is a karstic area affected by relevant geological risk mainly due to surface water and groundwater. In particular, sinkholes have been used to convey underground large amount of surface waters (rain water, waste water, etc.) aiming to avoid the flooding of wide land surfaces. However, during the last ten years this input of surface water underground has caused several cases of rapid subsidence. In this paper, the detailed study of two areas which have been recently affected by rapid subsidence is reported.

Key words: karst, sinkhole activity, collapse, Apulia, Italy.

Izvleček

UDC: $551.44(450.75)$

Gianluca Selleri \& Paolo Sansò \& Nicola Walsh: Kras v regiji Salento (Apulia, južna Italija): omejitve pri upravljanju

Polotok Salento je kraško območje s precejšnjim tveganjem, povezanim s površinsko in podzemno vodo. Da bi preprečili poplavljanje, so velike količine površinskih voda kanalizirali v vrtače. Zaradi tega je v zadnjih letih na večih mestih prišlo do hitrega pogrezanja in udiranja tal. Članek obravnava dve področji, kjer je do tega prišlo.

Ključne besede: kras, urejanje ponorov, udor, Apulia, Italija. 


\section{INTRODUCTION}

The Salento peninsula is a karstic area showing a high geological hazard as proved by the numerous problems occurred during recent years linked to the management of the karstic environment. In particular, the seasonally prolonged flooding of the numerous karstic and tectonic depressions which studded the Salento landscape is one of the most serious problems. Since the second half of XIX century and during the 30's, 50's and 70's of last century numerous hydraulic works have been carried out to improve the flow of surface waters into the underground circuit through karstic sinkholes.

In the 80's, larger and larger amounts of surface waters coming from urbanized areas were conveyed underground by means of wells, some hundreds meters deep, into the sea water intruded by the nearby coast. However, a recent law does not allow this solution any more whereas it allows the discharge of waste waters into the sea, lakes, rivers and, in some cases, on the soil. For this reason, the amount of surface waters flowing into endorheic basins and into the sinkholes is expected to increase significantly in the future.

However, during the last ten years the flow of large amounts of surface water underground has produced in several cases rapid subsidence phenomena which must be taken into account for a sustainable land management.

In this paper the results are reported of a detailed study on two areas where rapid subsidence events occurred because of the input of large amount of surface waters.

\section{GEOLOGICAL AND MORPHOLOGICAL SETTING}

The Salento peninsula is the southernmost emerged part of a plate which constitutes the foreland of both east-verging Apenninic and west-verging Dinaric orogens. It comprises a Mesozoic carbonatic sequence more than $6000 \mathrm{~m}$ thick - the Calcari delle Murge unit - overlain by thin deposits of Neogene and Quaternary age (Ciaranfi et al.1992).

The landscape of the Salento peninsula is composed of low sediplains alternating with narrow ridges, NNW-SSE trending and up to $200 \mathrm{~m}$ a.s.l. high (Fig. 1).

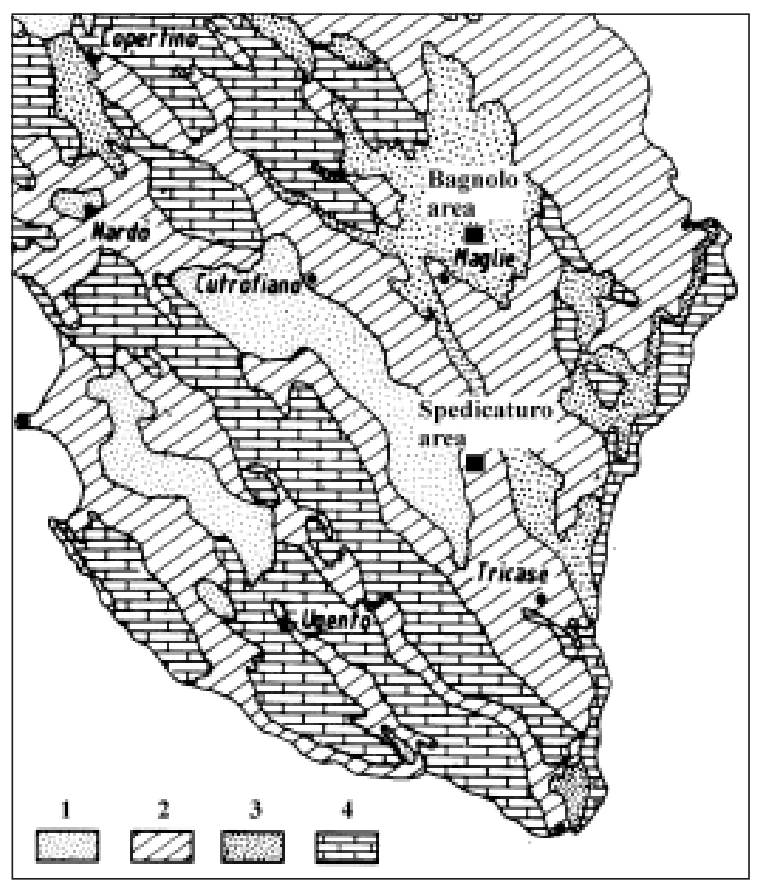

Fig. 1: Geological map of southern Salento and geographical position of studied areas. Legend: 1 - pre-Neogene units; 2 - Miocene units; 3 - Plio-Pleistocene units; 4 - Middle-Upper Pleistocene sands and clays. 
A number of karstic morphogenetic phases developed under different climates during the continental periods which followed from the end of Cretaceous to the present. The ancient karst surfaces were fossilized during marine transgressions and partially re-exposed during the regressive phases.

The drainage network is poorly developed. It is composed of short endorheic streams which flow into karstic sinkholes or into depressions and of relict valleys linked to ancient shorelines.

The Salento peninsula is marked by a wide, deep aquifer flowing into the Mesozoic limestones which rests on sea-water intruded from the nearby coastal area (Ghyben-Herzberg principle). However, a number of shallow water tables are host in the more recent deposits.

\section{FIRST EXAMPLE: THE BAGNOLO DEL SALENTO SINKHOLE}

The studied area shows a karstic landscape shaped on Miocene carbonatic rocks mantled by a sandy-silty cover of Upper Pleistocene age. At present this cover fills dolinas and the main closed depressions whereas the carbonatic bedrock crops out widely. A well-developed cryptokarst which formed most likely during the Upper Pleistocene can also be recognized in the area.

The sinkhole activity event occurred inside a small, broad depression where important urbanization works and some buildings are planned. The surplus of water coming from a big reservoir of drinking water flows at this depression to be conveyed underground. Until the ' 80 s the flow of water into the depression occurred only a few times whereas afterwards the flow periods became more frequent and prolonged. At present, a continuous flow of water with variable water load can be observed.

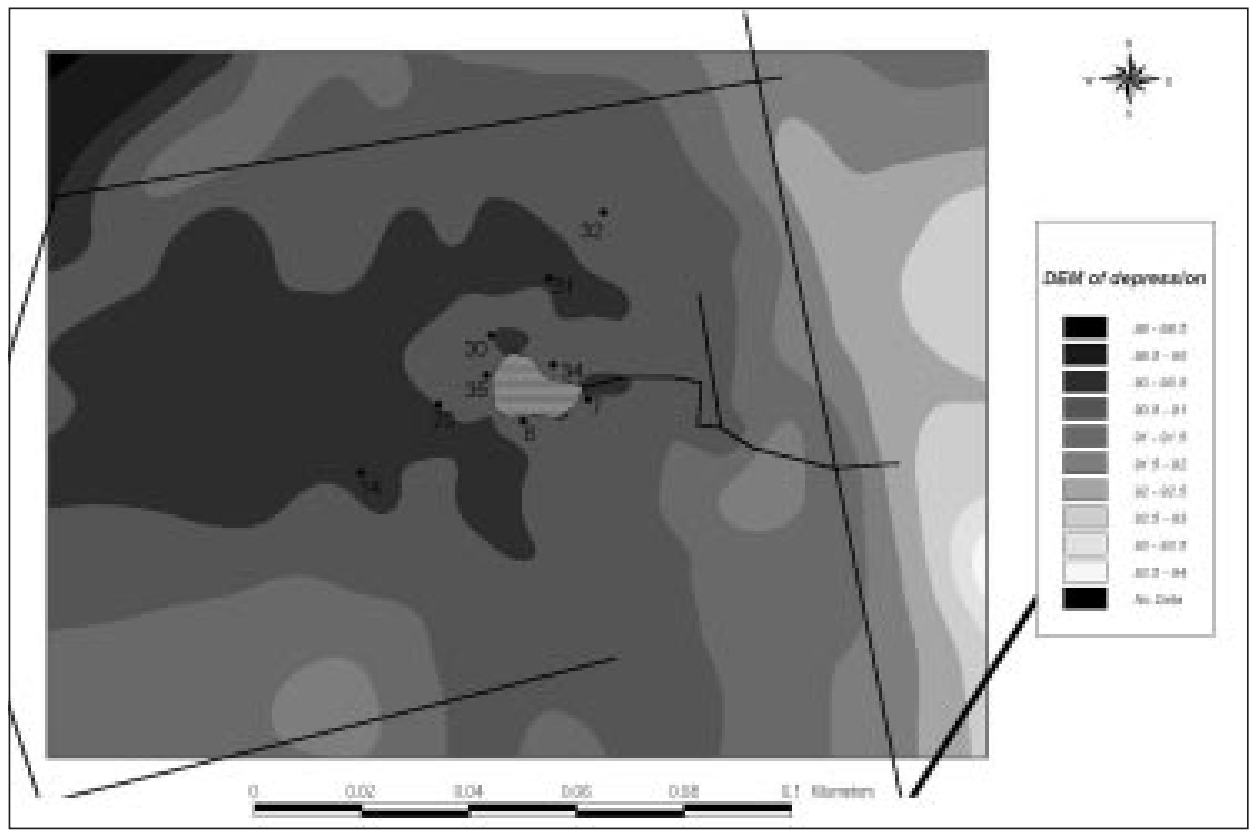

Fig. 2: Digital elevation model of Bagnolo del Salento depression. 


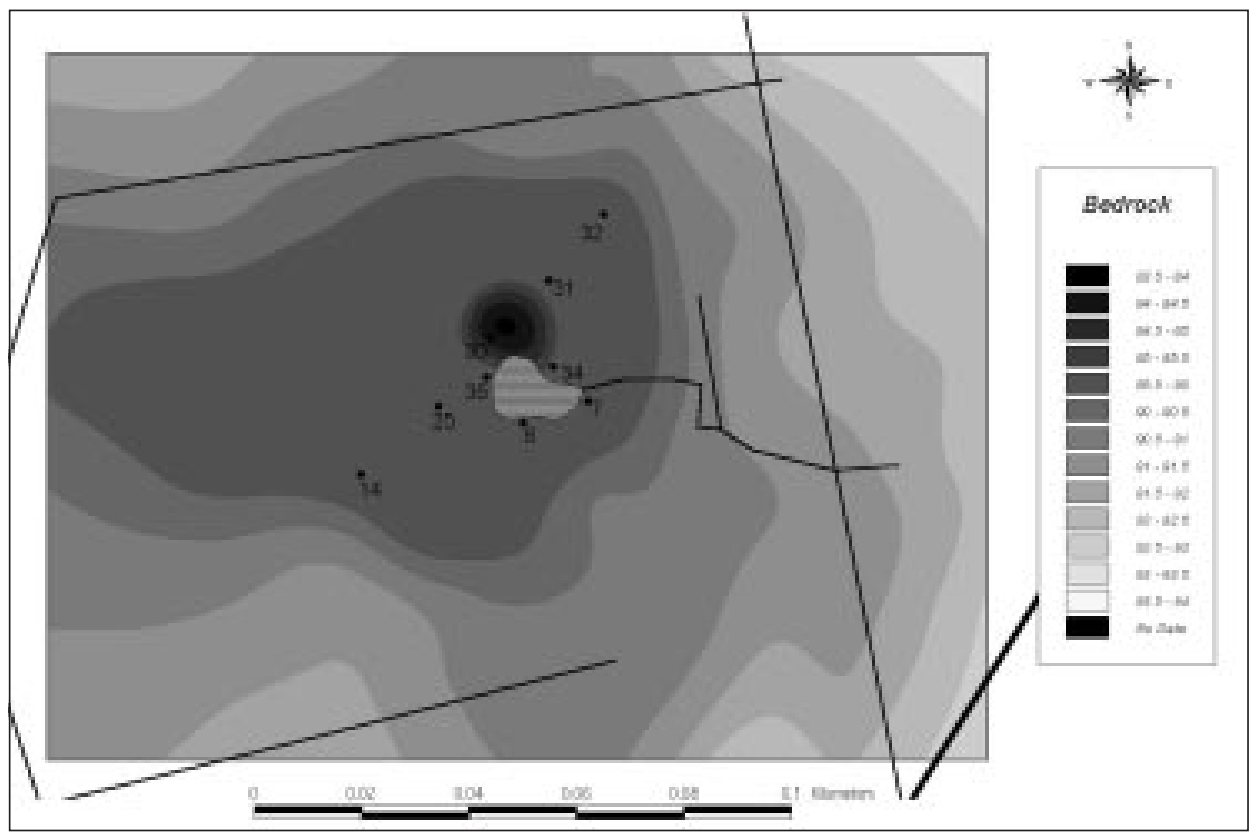

Fig. 3: Digital elevation model of bedrock reconstructed in Bagnolo del Salento depression.

A small sinkhole developed at the lowest part of the depression in 1990, during a flooding period lasting some weeks. Soon after the sinkhole development, a wide karstic cave which was not surveyed could be observed. Afterwards, a small lake fed by reservoir surplus developed inside the sinkhole (Photo 1).

Colluvial deposits, showing at their top a brownish soil up to $1.5 \mathrm{~m}$ thick, completely fill the depression. The bedrock morphology has been reconstructed by means of 35 penetrometric tests and a detailed topographic survey (Fig. 2, 3). The survey reveals that a cone-shaped vertical conduit, from 4 to $25 \mathrm{~m}$ wide and about $7 \mathrm{~m}$ deep, can be recognized at the bottom of the broad depression, just below the sinkhole (Fig. 4, 5).

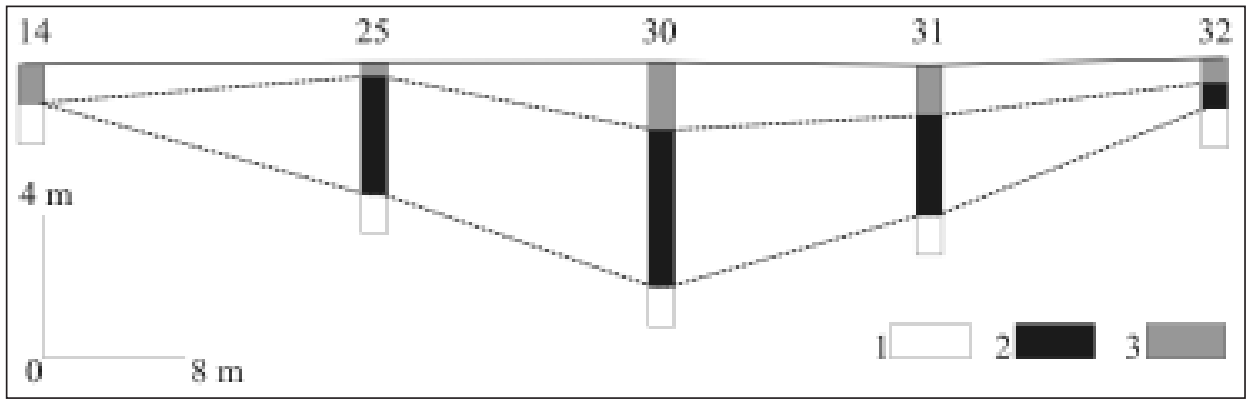

Fig. 4: Geological cross section of Bagnolo del Salento depression.

Legend: 1-Miocene calcarenites; 2 - Sandy colluvial deposits; 3 - Brownish soil. 


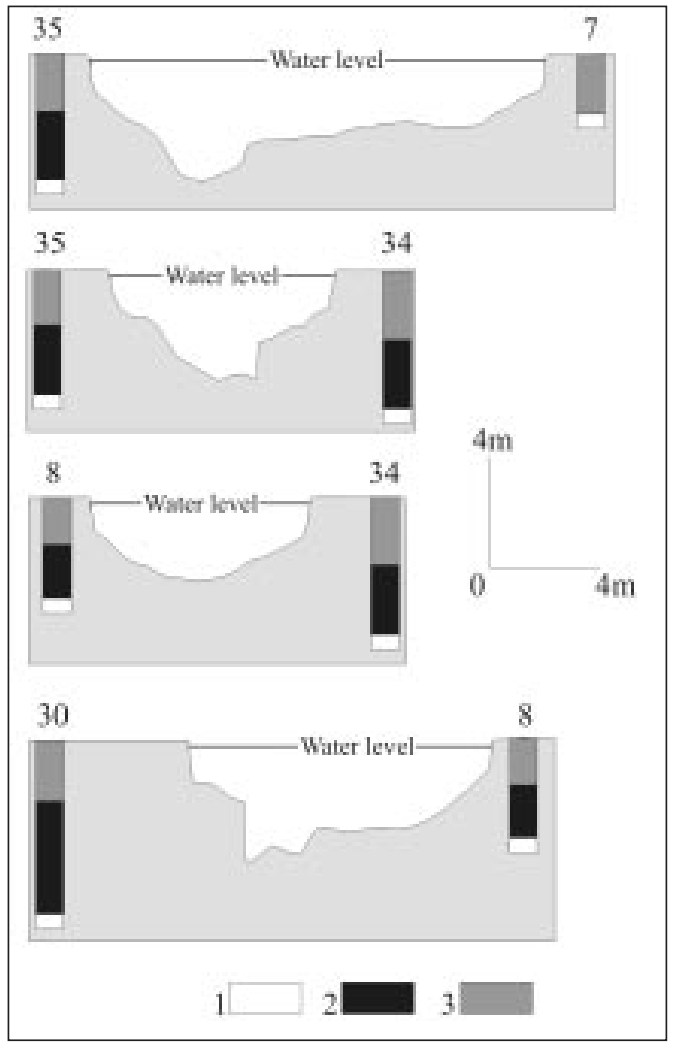

Fig. 5: Geological cross section of Bagnolo del Salento sinkhole. Legend: 1- Miocene calcarenites; 2 - Sandy colluvial deposits; 3 - Brownish soil.
The local stratigraphic sequence has been reconstructed by means of geophysical survey (VES and seismic refraction profiles) as well as bore-holes. The Miocene deposits, about $20 \mathrm{~m}$ thick, lay directly on the Mesozoic limestones. The lowest levels are made of Burdigalian Lower Messinian marly calcarenites which shade upward into a sequence of limestones, marly limestones and calcarenites, about $9 \mathrm{~m}$ thick whose age has been referred to the pre-evaporitic Lower Messinian.

The detailed survey of the area reveals that the sinkhole activity was produced by the sinking of the colluvial deposits which fill the depression through the small dolina opening at its bottom. This process has been induced by the frequent, long flooding of the lowest part of the depression due to the flow of the reservoir surplus water. Moreover, the study allows definition of the area that may be affected by new episodes of sinkhole activity and the identification of the best site for buildings.

\section{THE SECOND EXAMPLE: THE SPEDICATURO CAVE COLLAPSE SINKHOLES}

The second example has been observed in an endorheic area, about $270 \mathrm{~km}^{2}$ wide, placed in the central part of southern Salento. This area stretches between two narrow morphostructural limestone ridges and is characterized by unpervious calcareous marls belonging to different sedimentary cycles of Middle-Upper Pleistocene age. These last rocks cover a basement composed of different units cropping out along two main depressions placed at the foot of the main border fault scarps.

An important karstic phase developed in response to the input of surface water to the bordering depressions and to an Upper Pleistocene tectonic phase. This phase has been responsible for the development of numerous sub-cilindrical collapse sinkholes (locally named Vore) at the end of short, temporary streams. Land reclamation works made in the area since 1930 have modified the path of major streams and the relative drainage basins. 


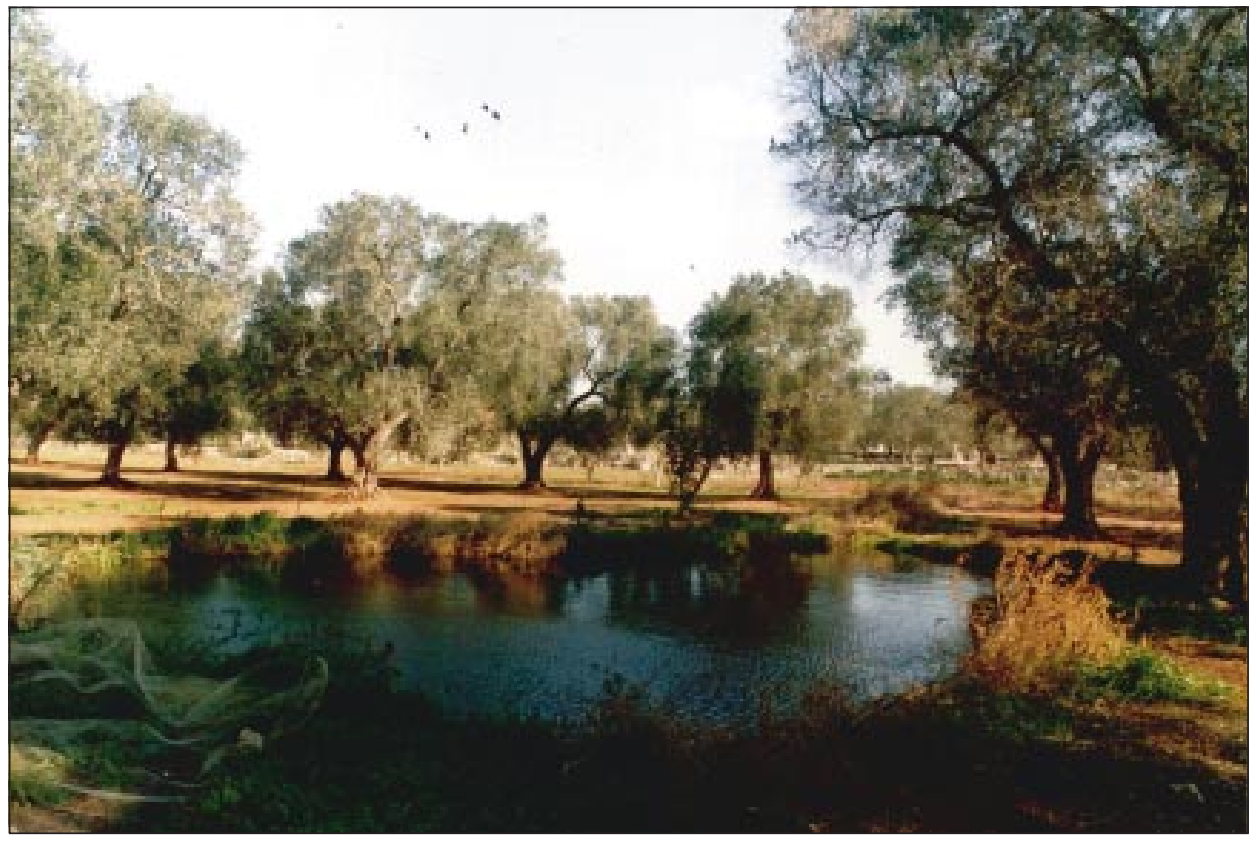

Photo 1: A view of artificial lake inside the Bagnolo del Salento sinkhole.

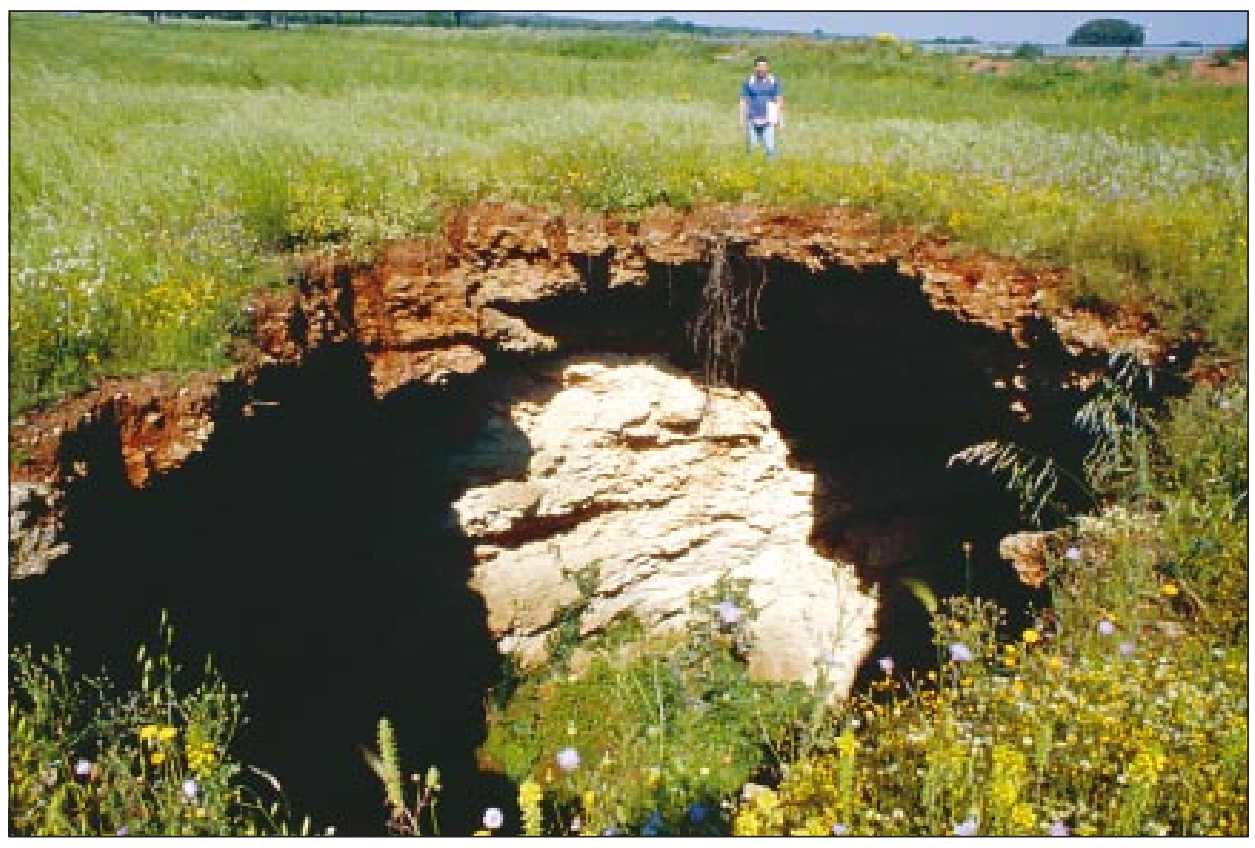

Photo 2: A view of Spedicaturo cave collapse sinkhole (Vora Nuova) formed the 13 March 1996. 
The 13 March 1996 a cave collapse sinkhole, about $19 \mathrm{~m}$ deep and $20 \mathrm{~m}$ wide (Photo 2), formed in an area marked by two older collapse dolinas which received the surface water collected by a drainage basin about $15.56 \mathrm{~km}^{2}$ wide. The collapse phenomena are most likely linked to the surface and groundwater circulation as well as to the particular lithostratigraphy of the area (Fig. 6). This last area is made of Lower Pleistocene silt and calcareous clayey sands at the lowest level, followed upward by clinostratified calcarenites with different grade of cementation. Joints show the same strike of clinostratification and a slope of about $90^{\circ}$. The phreatic water table is placed at about $25 \mathrm{~m}$ below the topographic surface.

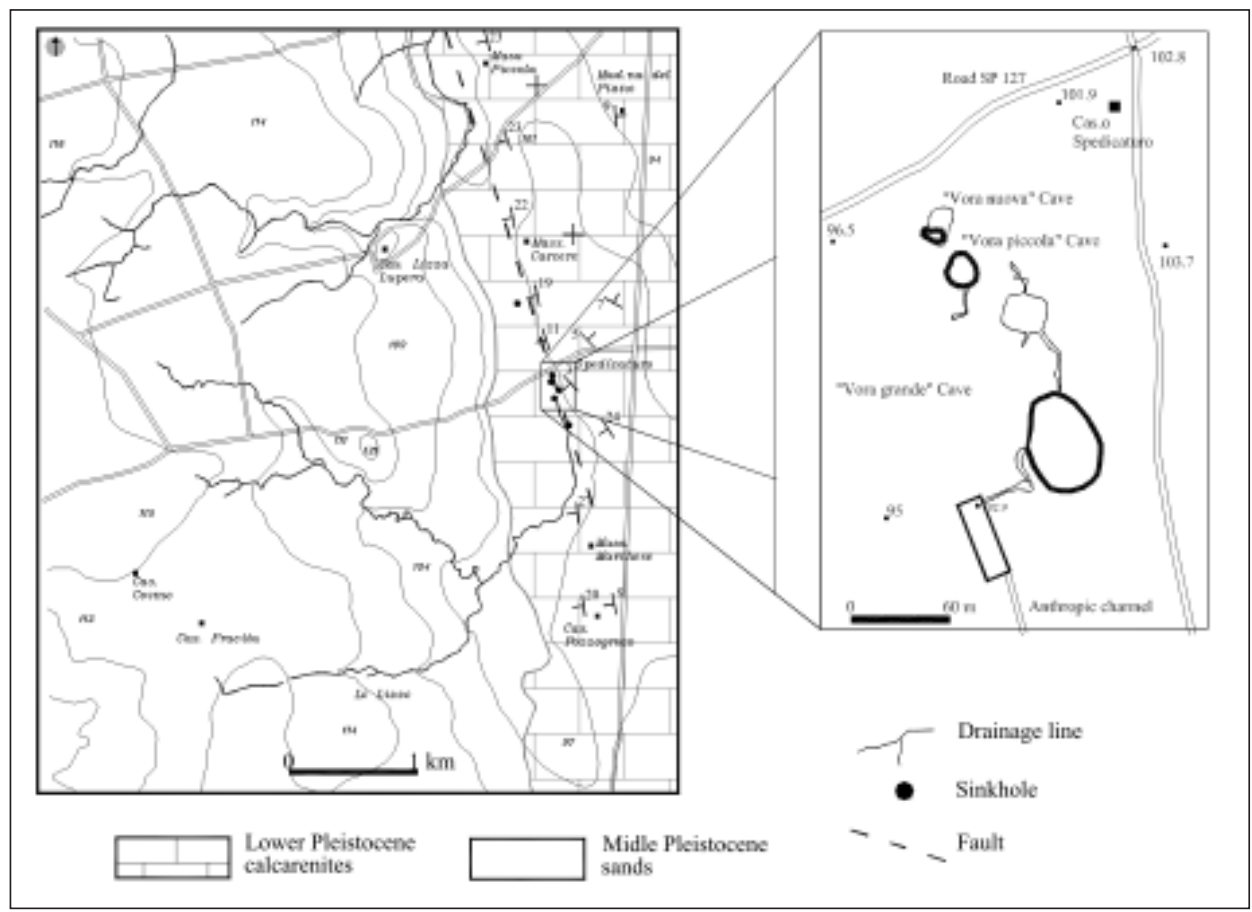

Fig. 6: Geological map of Spedicaturo area. In the box the position of collapse dolinas and karstic system is shown.

Karstic caves developed generally in the silty and sandy levels showing the roof made of clinostratified calcarenites. A geophysical survey suggests the presence of some conduits about $30 \mathrm{~m}$ below ground surface a few meters to the north of the new collapse dolina (Carrozzo et al. 1997).

Around 1970, hydraulic works were carried out to improve the flow of surface water into the karstic system. At present, the hydrographic network shows $14 \mathrm{~km}$ of length and a drainage basin of $15.56 \mathrm{~km}^{2}$. The network is made of a concrete main channel, about $4 \mathrm{~km}$ long, with trapezoidal cross section, about $10 \mathrm{~m}^{2}$ wide, a main stream about $5 \mathrm{~km}$ long with natural banks covered by 
vegetation and about $5 \mathrm{~km}$ of secondary, smaller streams. The main channel flows in a concrete pool (20 x $10 \mathrm{~m}$ and $4 \mathrm{~m}$ deep) which was built upstream the sinkhole aiming to reduce surface waters velocity and to decrease the solid load.

The groundwater circulation is influenced by rain distribution. During rainy periods surface waters flow underground through a sinkhole which opens at the NE corner of concrete pool. The sinkhole activity occurred in the 1996 during a storm when the flow of a large amount of surface waters into the underground circuit occurred. In fact, inside the newly formed collapse dolina a turbulent flow of water had been observed for several hours.

The main causes which produce these collapse phenomena are linked to the particular lithological and mechanical properties of outcropping rocks and to the erosive effects of turbulent flow of groundwater which produces the widening of underground cavities, mainly inside the silt and clayey-calcareous sands (Fig. 7). Hydraulic works have most likely increased the amount and the velocity of water flowing underground, enhancing sinkhole activity.

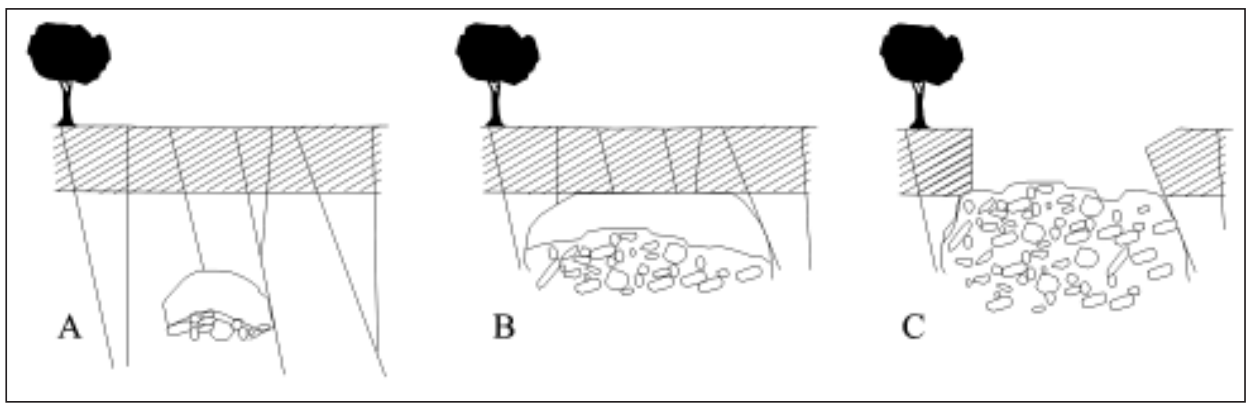

Fig. 7: Model of Spedicaturo cave collapse sinkhole genesis: a) the widening of the cavity is produced by mechanical erosion due to turbulent groundwater flow; b) the cavity widens horizontally along the weaker, lower layers assuming a shape influenced by the joint network; c) the roof collapse along main joints produces the development of a cave collapse dolina.

\section{CONCLUSIONS}

The described examples stress the necessity to define the morphological, geological and hydrogeological features of the karst system in the Salento region as a basis for correct land management and for risk assesment and its mitigation. The input of large amount of surface water underground through karstic sinkholes, in fact, can produce relevant phenomena of rapid subsidence which should be properly assessed.

The increasing necessity to convey surface waters into endorheic basins and into the sinkholes should be accomplished by the definition of the amount of water to discharge and by the individuation of karstic sinkholes more suitable to this aim. 


\section{REFERENCES}

Carrozzo, M. T., Delle Rose, M., Federico, A., Negri, S. \& Quarta, T. 1997: Individuazione con georadar di cavità carsiche nella zona di Nociglia (Lecce). - $15^{\circ}$ Congresso Nazionale di Geofisica, Roma.

Ciaranfi, N., Pieri, P. \& Ricchetti, G. 1992: Note alla carta geologica delle Murge e del Salento (Puglia centro-meridionale). - Mem. Soc. Geol. It., 106, 449-460, Roma.

Colombi, A., Di Loreto, A., Nolasco, F., Capelli, G. \& Salvati, R. 2001: The purposes of the main sinkhole project in the Latium Region of central Italy. - Geotecnical and Environmental Application of Karst Geology and Hidrology, 73-76, Beck and Herring Eds.

D’Alessandro, A., Mastronuzzi, G., Palmentola, G. \& Sansò, P. 1994: Pleistocene deposits of Salento leccese (Southern Italy): Problematic relationships. - Boll. Soc. Paleontol.It., 33(2), 257-263.

Gams, I. 1994: Types of contact karst. - Geogr. Fis. Dinam. Quat., 17, 37-46.

Gams, I. 2001: Notion and forms of contact karst. - Acta Carsologica, 30/2, 33-46, Ljubljana.

Palmentola, G. 1987: Geological and geomorphological outlines of the Salento leccese region (Southern Italy). - Atti del Convegno sulle conoscenze geologiche del territorio salentino. Lecce 12 dicembre 1987. Quaderni di Ricerche del Centro Studi Geotecnici e di Ingegneria Lecce, 11, 7-23, Lecce.

Selleri, G., Sansò, P. \& Walsh, N. 2002: The contact karst landscape of Salento peninsula (Apulia, southen Italy). In: Evolution of Karst from prekarst to cessation, 275-281, Postojna.

Sowers, G. F. 1996: Building on Sinkholes. - ASCE Press, American Society of Civil Engineers, p. 202, New York. 